Review Article

\title{
Reinforcement and Maintenance of Human Resources for Health Systems during Long-Term Crises: A Systematic Review of Systematic Reviews
}

\author{
Amir Mohammad Salehi $(\mathbb{D}),{ }^{1}$ Salman Khazaei $(\mathbb{D}),{ }^{2}$ Motahareh Masumi $\left(\mathbb{D},{ }^{3}\right.$ \\ Farnaz Shavandi $\left(\mathbb{D},{ }^{1}\right.$ Mostafa Kavand $\mathbb{D},{ }^{4}$ Ensiyeh Jenabi $\mathbb{D},{ }^{5}$ and Mahnaz Khatiban ${ }^{6}{ }^{6}$ \\ ${ }^{1}$ Student Research Committee, Hamadan University of Medical Sciences, School of Medicine, Hamadan, Iran \\ ${ }^{2}$ Research Center for Health Sciences, Hamadan University of Medical Sciences, Hamadan, Iran \\ ${ }^{3}$ Student Research Committee, Hamadan University of Medical Sciences, School of Public Health, Hamadan, Iran \\ ${ }^{4}$ Student Research Committee, Hamadan University of Medical Sciences, School of Nursing and Midwifery, Hamadan, Iran \\ ${ }^{5}$ Autism Spectrum Disorders Research Center, Hamadan University of Medical Sciences, Hamadan, Iran \\ ${ }^{6}$ Mother and Child Care Research Center, Department of Ethics Education in Medical Sciences, \\ Department of Medical-Surgical Nursing, School of Nursing and Midwifery, Hamadan University of Medical Sciences, \\ Hamadan, Iran
}

Correspondence should be addressed to Mahnaz Khatiban; mahnaz.khatiban@gmail.com

Received 20 September 2021; Revised 13 October 2021; Accepted 19 October 2021; Published 31 October 2021

Academic Editor: Yan-Ren Lin

Copyright (C) 2021 Amir Mohammad Salehi et al. This is an open access article distributed under the Creative Commons Attribution License, which permits unrestricted use, distribution, and reproduction in any medium, provided the original work is properly cited.

\begin{abstract}
Background. Human resources are one of the most critical organizational resources, the reinforcement and maintenance of whom require much energy in health organizations, particularly in long-term crises. Many methods have been suggested in this regard; however, there is a need for their integration and clarification. Methods. We systematically searched the international databases, including PubMed, Scopus, and Web of Science, from 2003 to April 2021by using some relevant keywords. The quality of the included studies was assessed using the AMSTAR checklist. Results. The search resulted in 1613 papers, among which there were 16 systematic reviews. The studies addressed a wide range of problems and solutions. Twelve items and four items were classified with moderate quality (AMSTER score 5-8) and high quality (AMSTER score 9-11), respectively. Half of the studies $(n=8)$ dealt with mental and psychological problems resulting from crises as the most important factor in the decline of health system staff's durability in organizations. They also provided different solutions such as mental health counselling during and after the crisis, flexible work schedule, promoted trust in the organization, support of staff's family, and enhanced awareness to support employees. And the other articles addressed managerial problems as the most critical factor in the decline of health system staffs durability in organizations and proposed solutions such as suitable planning before, during, and after the crisis and the use of material and spiritual incentives to increase the employees' motivation and organizational resilience to maintain the staff. Conclusion. In the present review study, three dimensions (namely, resilience, motivation-hygiene measures, and development of manager's soft skills) are considered as the main factors reinforcing and maintaining human resources in the health systems in long-term crises and disasters.
\end{abstract}

\section{Introduction}

The rate of crises and the number of their adverse consequences are increasing worldwide, which usually occur fast and suddenly [1]. According to Kristine Qureshi's report in
2005, the collected data on the sudden prevalence of severe acute respiratory syndrome (SARS) indicate that, in these crises, healthcare staff might be reluctant to work $[2,3]$. Among the variety of crises, the nurses' minimum rate of reluctance to work (48\%) was related to the SARS period [4]. 
Their reluctance could negatively influence the healthcare system's potentials to meet the needs of a sudden increase in the number of patients under such a condition $[5,6]$. On the other hand, healthcare staff, in particular nurses, who make up the largest number of healthcare providers and play the pivotal role in crises response and care, are required to have sufficient knowledge, skills, competencies, and adequate preparation to respond to crisis $[1,7]$. In this regard, the findings reported by Said and Chiang indicate that nurses should focus on psychological preparedness to develop and create better educational plans to reinforce knowledge and care abilities required in crises [1].

Modern challenges have been diverse and include a complicated range of issues such as climate changes, severe economic downturns, and political instabilities. In this interconnected world, these main issues could be a sudden threat to organizations' life and survival. That is why these kinds of challenges encourage organizations to stay adaptable and responsive while organizing and managing their staff [8]. Under such conditions, resilience makes systems adapt to emerging challenges and let organizations continue their activities in the new condition [9]. However, organizations have faced a huge challenge with the COVID-19 outbreak, which makes them manage their employees using different technical, physical, and social-psychological techniques never experienced before [8].

In a crisis, one of the critical duties of human resources (HR) management is maintaining employees' health while preserving their morals and loyalty and encouraging them to continue their activities in line with the organization's goals [10]. COVID-19 has created a challenging condition, particularly for the HR management since the HR department is one of the most pivotal parts of modern organizations, the role of which becomes even more highlighted during crises and in the crisis management $[5,8]$. In this situation, many employees have been encouraged to work in their homes, and their managers monitor tasks remotely; however, health organizations, especially those with emergency personnel and healthcare specialists, need their staff in their workplace [2]. Under this condition, human resource managers should help the staff deal with changes occurring in the workplace and social environment and adapt themselves to these changes [8] since it affects how personnel are supposed to make decisions. Moreover, plans, policies, and organizational decisions should be made based on the best available evidence [3]. Accordingly, this systematic review was to detect and integrate techniques of reinforcing and maintaining human resources in long-term crises in healthcare organizations.

\section{Materials and Methods}

The paper is presented in accordance with the Preferred Reporting Items for Systematic Reviews (PRISMA) reporting checklist (Supplementary 1).

2.1. Search Strategy. A comprehensive search was first conducted on PubMed, Scopus, Web of Science, and Cochrane databases from 2003 due to the occurrence of the first long-term crisis (SARS) to April 2021 to detect the best techniques to maintain human resources of the health system during crises and under stressful conditions. To this end, the following keywords, either alone or by conjunctions of "and" or "or," were used to find relevant papers with the concerned keywords in the title, abstract, and keywords sections: "Management," "Strategy," "Method," "Support," "Maintenance," "Sustaining," "Compliance," "Human Resources," "Healthcare worker," "Physicians," "Doctors," "Nurses," "Medical staff," "Crisis," "Disaster," "Catastrophic," "Systematic review," Long term," and "Longterm." We manually searched the reference lists to identify studies missed. In addition, we contacted with authors included articles for identifying more studies.

2.2. Study Selection. Inclusion criteria were systematic reviews in English, full-text papers, and healthcare workers as the statistical population. Exclusion criteria were nonsystematic reviews, irrelevant studies, qualitative studies, studies presented in conferences and/or seminars, and letters to the editors.

To select the articles and extract the data, initial screening was based on titles and abstracts. The articles were evaluated independently. The abstracts lacking data were revised for full-text assessment. Then two researchers individually evaluated the full text of the articles and determined their fitness (Figure 1).

2.3. Data Extraction and Quality Assessment. Two researchers (A. S. and M. M.) extracted data regarding standard criteria, and the results were reviewed by two senior researchers (M. K. and S. K.). The extracted data included the first author, year of publication, period, objectives, number of studies, and findings. The studies were evaluated using a checklist entitled "Measurement Tool to Assess Systematic Reviews (AMSTAR)" [11] to assess methodological quality (Supplementary 2). The tool consists of 11 items and has good face and content validity for measuring the methodological quality of systematic reviews.

\section{Results}

Based on Table 1, findings are classified in three areas of "organizational resilience," "motivation-hygiene measures," and "managers' soft skills." These factors can help healthcare workers to resist and keep on in long-term crises.

3.1. Organizational Resilience. We categorized the organizational factors such as material resources, scarce resource allocation management strategies, preparation, planning, diverse programming for critical episodes, crisis treatment standards, critical incident stress management, risk management, social media, government's measures, leadership methods, organizational culture, special training program, education systems, information management, cooperation, and peer support in a set and according to the literature labeled it as "organizational resilience." According to the 


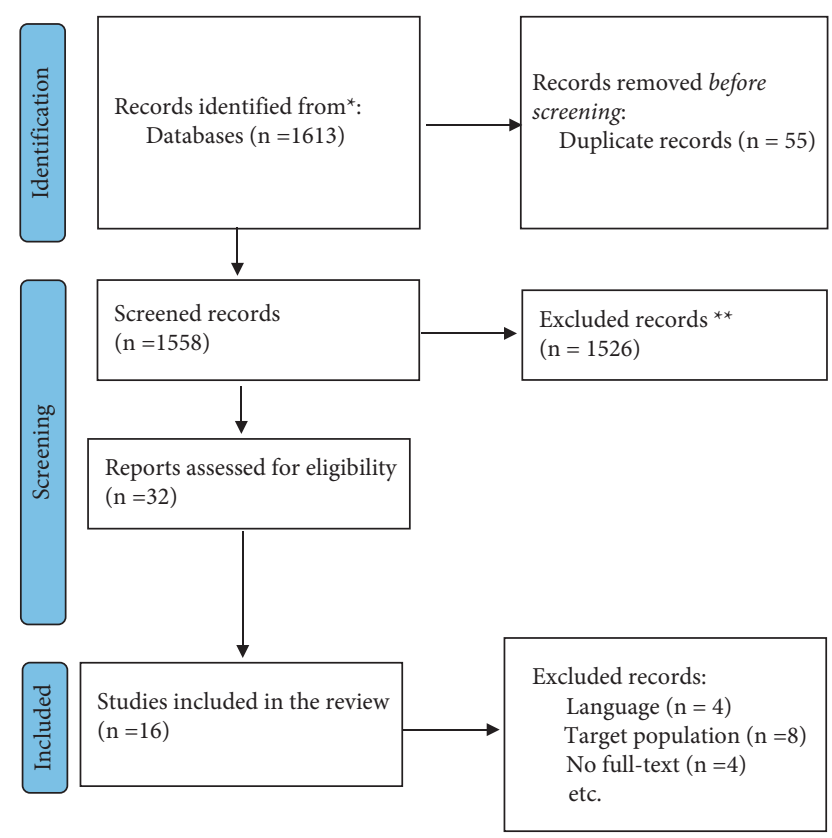

FIGURE 1: Reporting items for systematic reviews flowchart of the included studies.

standards, organizational resilience is the organization's ability to predict, plan, react, and adapt to crisis in order to survive and succeed $[27,28]$. The organizational resilience has a significantly positive relation to the organizational members' intentions for contributing to organizational effectiveness after a crisis situation [29].

3.2. Motivators and Hygiene Factors. The human resource features factors are thought to be relevant to the maintenance and motivation factors to respond to the crisis. These are organized into motivators and hygiene factors category. Hygiene or maintenance factors do not motivate employees; however, they merely prevent dissatisfaction and maintain the status [30]. In our study, hygiene factors covered aspects such as providing safety and protective equipment, availability of resources, shift flexibility, rest, workload, financial awards, and job promotion. Motivation factors were inherently job-related and, in this study, motivators reflect the pursuing professional education, role transparency, footprint of the organization's risk, and adaptive capacity. Managers should be aware that satisfaction is associated with motivational factors and that dissatisfaction is associated with hygiene factors.

3.3. Managers' Soft Skills. "Soft skills" refer to all the competencies that are not directly related to a specific task. The soft skills enable managers to succeed in an increasingly complex, interconnected, and rapidly changing situation such as crisis. The social abilities, language and communication capability, and friendliness and team working ability, as well as other personality traits that characterize relationship between people are soft skills [31]. So, listening skills, emotional skills, empathy, complex problem-solving, creative strategies to support and manage personnel, critical thinking, learning to learn, collaboration, creating opportunities for development for the employees working under crisis conditions, and generally sparing efforts to build trust were classified in the managers' soft skills category.

\section{Discussion}

In this study, some review studies on the techniques causing the reinforcement and maintenance of human healthcare resources under the long-term crisis conditions were examined, according to which three main dimensions were detected.

The first dimension was organizational resilience. Resilience is defined as an organization's capability to continue its activities in line with its goals in the presence of challenges. Resilience not only increases the system's capacity to resist strikes but also adapts and changes in accordance with the challenges. In this regard, managers need to consider crises in advance and adopt some management techniques such as the accelerated successive overrelaxation and ASOR method, identify the organization's weaknesses and strengths, and make necessary plans [9]. This planning is also necessary for the provision of human resources. In crises, workers could be classified into three groups. The first group includes workers who work in the organization and continue their activities during the crises period. This group of workers might either be satisfied with their jobs or not be satisfied and stay in the organization due to their lack of willingness to search for a new job and family commitments, while they are dissatisfied with their jobs. This is not good for the organization since such workers fail to be creative and dynamic and finally quit the organization when they find an appropriate job. Organization managers must take management measures to promote the satisfaction of dissatisfied and unmotivated workers because the lack of motivation could decrease the quality of service $[11,32]$. The second group includes workers lost because of job dissatisfaction, retirement, death, or other causes [32]. The third group encompasses workers coming to the organization during the crisis. These workers might be just graduated or senior students, who join the organization with the incentive of employment upon the call of the health system [32]. According to Collado-Boira, despite the threats of COVID19 , senior students were more willing to accept the government's request due to their social commitment and professional ethics [11].

In the three groups, job satisfaction is considered a critical factor in maintaining staff under crisis conditions. The other finding of this study was the necessity of motivation-hygiene measures, which are the activities performed by health managers and policymakers for their staff to help them maintain their morals. These measurements positively affect the organization's output, thus providing high-quality care since these outputs are the results of the staff's efforts.

Moreover, the motivation-hygiene measures decrease the likelihood of staff leaving service and changing job, thereby decreasing the organization's costs [33]. Factors such as job security, flexible attendance time, and 
TABLE 1: Summaries of the main points of the article.

\begin{tabular}{|c|c|c|c|c|c|c|c|c|}
\hline $\begin{array}{l}\text { Name of } \\
\text { the first } \\
\text { author }\end{array}$ & Year & Period & Objectives & Databases & $\begin{array}{l}\text { Number } \\
\text { of } \\
\text { reviewed } \\
\text { articles }\end{array}$ & Meta & Findings & Subset \\
\hline $\begin{array}{l}\text { Muller } \\
\text { et al. [12] }\end{array}$ & 2020 & $01.12 .2019-11.05 .2020$ & $\begin{array}{l}\text { 1. Investigating } \\
\text { the impact of the } \\
\text { COVID-19 } \\
\text { pandemic on } \\
\text { healthcare } \\
\text { workers' mental } \\
\text { health, including } \\
\text { (a) changes over } \\
\text { time, (b) } \\
\text { prevalence of } \\
\text { mental health } \\
\text { problems and } \\
\text { risk/resilience } \\
\text { factors, (c) } \\
\text { strategies and } \\
\text { resources used by } \\
\text { healthcare } \\
\text { providers to } \\
\text { protect one's } \\
\text { mental health, (d) } \\
\text { perceived need } \\
\text { and preferences } \\
\text { for interventions, } \\
\text { and (e) healthcare } \\
\text { workers' } \\
\text { understandings } \\
\text { of their mental } \\
\text { health during the } \\
\text { pandemic } \\
\text { 2. Describing the } \\
\text { interventions } \\
\text { assessed in the } \\
\text { literature to } \\
\text { prevent or reduce } \\
\text { negative impacts } \\
\text { on the mental } \\
\text { health of } \\
\text { healthcare } \\
\text { workers working } \\
\text { during the } \\
\text { COVID-19 } \\
\text { pandemic }\end{array}$ & $\begin{array}{l}\text { PubMed, CDC, } \\
\text { EMBASE, and } \\
\text { NIPH's }\end{array}$ & 59 & $\mathrm{~N}$ & $\begin{array}{l}\text { 1. Healthcare staff } \\
\text { in different } \\
\text { positions are } \\
\text { exposed to risks } \\
\text { such as } \\
\text { depression, } \\
\text { anxiety, and sleep } \\
\text { problems during } \\
\text { the COVID-19 } \\
\text { pandemic due to } \\
\text { different reasons } \\
\text { 2. Preparing } \\
\text { appropriate } \\
\text { personal } \\
\text { protective } \\
\text { equipment and } \\
\text { shift change } \\
\text { programs to allow } \\
\text { for rest in long- } \\
\text { term crises is } \\
\text { important }\end{array}$ & $\begin{array}{l}\text { Motivation- } \\
\text { hygiene } \\
\text { measures }\end{array}$ \\
\hline
\end{tabular}


TABle 1: Continued.

\begin{tabular}{|c|c|c|c|c|c|c|c|c|}
\hline $\begin{array}{l}\text { Name of } \\
\text { the first } \\
\text { author }\end{array}$ & Year & Period & Objectives & Databases & $\begin{array}{l}\text { Number } \\
\text { of } \\
\text { reviewed } \\
\text { articles }\end{array}$ & Meta & Findings & Subset \\
\hline $\begin{array}{l}\text { Cabarkapa } \\
\text { et al. [13] }\end{array}$ & 2020 & $2002-21.08 .2020$ & $\begin{array}{l}\text { 1. Investigating } \\
\text { psychological } \\
\text { disorders in } \\
\text { healthcare } \\
\text { workers }(\mathrm{HCV}) \\
\text { during severe } \\
\text { epidemics } \\
\text { 2. Identifying } \\
\text { strategies to solve } \\
\text { problems }\end{array}$ & $\begin{array}{l}\text { PubMed, } \\
\text { MEDLINE, and } \\
\text { CINAHL }\end{array}$ & 55 & $\mathrm{~N}$ & $\begin{array}{l}\text { 1. Psychological } \\
\text { consequences in } \\
\text { healthcare staff, } \\
\text { such as the risk of } \\
\text { problems and } \\
\text { anxiety, are } \\
\text { different. The fear } \\
\text { of unknown cases } \\
\text { is one of their } \\
\text { challenges } \\
\text { 2. The negative } \\
\text { mentality created } \\
\text { by family and } \\
\text { society increases } \\
\text { the negative effects } \\
\text { of stress } \\
\text { 3. Adaptative } \\
\text { methods are } \\
\text { different among } \\
\text { different cultures, } \\
\text { physicians, nurses, } \\
\text { and other } \\
\text { healthcare } \\
\text { employees }\end{array}$ & $\begin{array}{l}\text { Motivation- } \\
\text { hygiene } \\
\text { measures }\end{array}$ \\
\hline $\begin{array}{l}\text { Willis- } \\
\text { Shattuck } \\
\text { et al. [14] }\end{array}$ & 2008 & $1980-09.2007$ & $\begin{array}{l}\text { 1. Identifying } \\
\text { factors affecting } \\
\text { motivation } \\
\text { 2. Investigating } \\
\text { the effectiveness } \\
\text { of interventions } \\
\text { in improving } \\
\text { motivation and } \\
\text { reducing } \\
\text { healthcare } \\
\text { workers' } \\
\text { immigration in } \\
\text { developing } \\
\text { countries }\end{array}$ & $\begin{array}{c}\text { PubMed, ISI } \\
\text { Web of Science, } \\
\text { EMBASE/ } \\
\text { Medline, and } \\
\text { Google Scholar }\end{array}$ & 20 & $\mathrm{~N}$ & $\begin{array}{l}\text { The following } \\
\text { seven motivational } \\
\text { factors contribute } \\
\text { to maintaining } \\
\text { workers: } \\
\text { 1. Financial } \\
\text { awards } \\
\text { 2. Job promotion } \\
\text { 3. Pursuing } \\
\text { education } \\
\text { 4. Hospital } \\
\text { infrastructure } \\
\text { 5. Availability of } \\
\text { resources } \\
\text { 6. Hospital } \\
\text { management } \\
\text { 7. Appreciation }\end{array}$ & $\begin{array}{l}\text { Motivation- } \\
\text { hygiene } \\
\text { measures } \\
\text { Managers'soft } \\
\text { skills }\end{array}$ \\
\hline
\end{tabular}


TABle 1: Continued.

\begin{tabular}{|c|c|c|c|c|c|c|c|c|}
\hline $\begin{array}{l}\text { Name of } \\
\text { the first } \\
\text { author }\end{array}$ & Year & Period & Objectives & Databases & $\begin{array}{l}\text { Number } \\
\text { of } \\
\text { reviewed } \\
\text { articles }\end{array}$ & Meta & Findings & Subset \\
\hline Barasa [9] & 2018 & Till 31.12.2016 & $\begin{array}{l}\text { 1. Exploring how } \\
\text { resilience is } \\
\text { conceptualized } \\
\text { 2. Identifying } \\
\text { factors affecting } \\
\text { organizational } \\
\text { resilience and } \\
\text { how they are } \\
\text { nurtured }\end{array}$ & $\begin{array}{l} \\
\text { PubMed, } \\
\text { Econlit, } \\
\text { EBSCOHOST } \\
\text { databases, } \\
\text { Google, and } \\
\text { Google Scholar }\end{array}$ & 23 & $\mathrm{~N}$ & $\begin{array}{l}\text { Organizational } \\
\text { resilience is } \\
\text { affected by } \\
\text { material resources, } \\
\text { preparation, and } \\
\text { planning, } \\
\text { information } \\
\text { management, } \\
\text { sideways of } \\
\text { increasing } \\
\text { revenue, } \\
\text { government's } \\
\text { measures, } \\
\text { leadership } \\
\text { methods, } \\
\text { organizational } \\
\text { culture, human } \\
\text { capital, social } \\
\text { media, and } \\
\text { cooperation }\end{array}$ & $\begin{array}{l}\text { Organizational } \\
\text { resilience }\end{array}$ \\
\hline $\begin{array}{l}\text { Fernandez } \\
\text { et al. [15] }\end{array}$ & 2020 & Till 03.2020 & $\begin{array}{l}\text { Identifying } \\
\text { factors affecting } \\
\text { the provision of } \\
\text { high-quality } \\
\text { services by nurses } \\
\text { during the } \\
\text { epidemic }\end{array}$ & $\begin{array}{c}\text { CINAHL, } \\
\text { MEDLINE, } \\
\text { EMBASE, } \\
\text { PubMed, Google } \\
\text { Scholar, } \\
\text { Cochrane } \\
\text { Library, } \\
\text { MedNar, and } \\
\text { ProQuest }\end{array}$ & 28 & $\mathrm{~N}$ & $\begin{array}{l}\text { The nursing team } \\
\text { provide high- } \\
\text { quality care if the } \\
\text { following factors } \\
\text { are available: } \\
\text { 1. Physical and } \\
\text { emotional } \\
\text { supports } \\
\text { 2. Organization } \\
\text { and management's } \\
\text { timely response } \\
\text { and reaction }\end{array}$ & $\begin{array}{l}\text { Managers' soft } \\
\text { skills }\end{array}$ \\
\hline
\end{tabular}


TABle 1: Continued.

\begin{tabular}{|c|c|c|c|c|c|c|c|c|}
\hline $\begin{array}{l}\text { Name of } \\
\text { the first } \\
\text { author }\end{array}$ & Year & Period & Objectives & Databases & $\begin{array}{l}\text { Number } \\
\text { of } \\
\text { reviewed } \\
\text { articles }\end{array}$ & Meta & Findings & Subset \\
\hline $\begin{array}{l}\text { Anderson } \\
\text { et al. [16] }\end{array}$ & 2020 & $2008-9.12 .2019$ & $\begin{array}{l}\text { Investigating the } \\
\text { effectiveness of } \\
\text { organizational } \\
\text { peer support and } \\
\text { crisis-focused } \\
\text { psychological } \\
\text { interventions to } \\
\text { mitigate } \\
\text { posttraumatic } \\
\text { stress injuries } \\
\text { (PTSIs) among } \\
\text { public safety } \\
\text { personnel (PSP), } \\
\text { frontline } \\
\text { healthcare } \\
\text { professionals } \\
\text { (FHP), and other } \\
\text { relevant groups at } \\
\text { risk of } \\
\text { occupational } \\
\text { exposure to } \\
\text { potentially } \\
\text { psychologically } \\
\text { traumatic events } \\
\text { (PPTEs) }\end{array}$ & $\begin{array}{c}\text { PsycINFO, } \\
\text { PubMed, JSTOR, } \\
\text { Web of Science, } \\
\text { Wiley, Sage, } \\
\text { Taylor \& Francis, } \\
\text { Cambridge and } \\
\text { Oxford Journal } \\
\text { Online, Google } \\
\text { Scholar }\end{array}$ & 14 & $\mathrm{~N}$ & $\begin{array}{l}\text { Public safety } \\
\text { personnel (PSP) } \\
\text { and frontline } \\
\text { healthcare } \\
\text { professionals } \\
\text { (FHP) are often } \\
\text { exposed to } \\
\text { potentially } \\
\text { psychologically } \\
\text { traumatic events } \\
\text { (PPTEs), and the } \\
\text { increase in the } \\
\text { rates of } \\
\text { posttraumatic } \\
\text { stress injuries } \\
\text { (PTSIs) such as } \\
\text { frequent absences, } \\
\text { labeling, smoking } \\
\text { and drugs, and } \\
\text { suicide are also } \\
\text { noticed among } \\
\text { them } \\
\text { Measures such as } \\
\text { diverse } \\
\text { programming for } \\
\text { critical incident } \\
\text { stress debriefing, } \\
\text { critical incident } \\
\text { stress } \\
\text { management, peer } \\
\text { support, } \\
\text { psychological first } \\
\text { aid, and trauma } \\
\text { risk management } \\
\text { result in the } \\
\text { reduction of PTSI }\end{array}$ & $\begin{array}{l}\text { Organizational } \\
\text { resilience, } \\
\text { Managers' soft } \\
\text { skills }\end{array}$ \\
\hline
\end{tabular}


TABle 1: Continued.

\begin{tabular}{|c|c|c|c|c|c|c|c|c|}
\hline $\begin{array}{l}\text { Name of } \\
\text { the first } \\
\text { author }\end{array}$ & Year & Period & Objectives & Databases & $\begin{array}{l}\text { Number } \\
\text { of } \\
\text { reviewed } \\
\text { articles }\end{array}$ & Meta & Findings & Subset \\
\hline $\begin{array}{l}\text { Aoyagi } \\
\text { et al. [17] }\end{array}$ & 2015 & 04.2013-2015 & $\begin{array}{l}\text { 1. Investigating } \\
\text { willingness to } \\
\text { work in HCWs } \\
\text { during the flu } \\
\text { pandemic } \\
\text { 2. Identifying } \\
\text { factors affecting } \\
\text { the willingness to } \\
\text { work }\end{array}$ & $\begin{array}{l}\text { MEDLINE, } \\
\text { EMBASE, Web } \\
\text { of Knowledge, } \\
\text { SCOPUS, } \\
\text { AMED, ASSIA, } \\
\text { BioEthicsWeb, } \\
\text { CINAHL, } \\
\text { Cochrane } \\
\text { Library, } \\
\text { PsychINFO, } \\
\text { Google Scholar, } \\
\text { and OpenGrey }\end{array}$ & 43 & $\mathrm{Y}$ & $\begin{array}{l}\text { The following } \\
\text { factors were } \\
\text { associated with an } \\
\text { increase in the } \\
\text { willingness to } \\
\text { work in healthcare } \\
\text { workers, } \\
\text { physicians, and } \\
\text { nurses: } \\
\text { 1. Permanent } \\
\text { employment } \\
\text { 2. Perceived } \\
\text { personal safety } \\
\text { 3. Awareness of } \\
\text { the pandemic risk } \\
\text { and clinical } \\
\text { knowledge of } \\
\text { epidemics } \\
\text { 5. Teaching how to } \\
\text { respond to the } \\
\text { epidemic } \\
\text { 6. Self-confidence } \\
\text { in personal skills. } \\
\text { However, } \\
\text { childcare was } \\
\text { significantly } \\
\text { associated with a } \\
\text { reduced } \\
\text { willingness to } \\
\text { work during the } \\
\text { flu pandemic. }\end{array}$ & $\begin{array}{l}\text { Motivation- } \\
\text { hygiene } \\
\text { measures } \\
\text { Managers'soft } \\
\text { skills }\end{array}$ \\
\hline $\begin{array}{l}\text { Ashcroft } \\
\text { et al. [18] }\end{array}$ & 2020 & $1996-19.03 .2020$ & $\begin{array}{l}\text { 1. Reviewing } \\
\text { disaster training } \\
\text { courses for } \\
\text { medical students } \\
\text { systematically } \\
\text { 2. Describing the } \\
\text { educational } \\
\text { structure and } \\
\text { methodology } \\
\text { 3. Evaluating } \\
\text { both } \\
\text { preparedness for } \\
\text { disaster medicine } \\
\text { and learning } \\
\text { outcomes to } \\
\text { inform the } \\
\text { development of } \\
\text { COVID-19- } \\
\text { specific training } \\
\text { programs }\end{array}$ & $\begin{array}{l}\text { EMBASE, } \\
\text { Medline, and } \\
\text { Cochrane }\end{array}$ & 23 & $\mathrm{~N}$ & $\begin{array}{l}\text { To attract medical } \\
\text { students aimed at } \\
\text { helping dealing } \\
\text { with COVID-19, } \\
\text { there is a need for } \\
\text { a special training } \\
\text { program for them. } \\
\text { This study } \\
\text { indicates that } \\
\text { medical students } \\
\text { trained by } \\
\text { appropriate } \\
\text { education systems } \\
\text { can play a pivotal } \\
\text { role in managing } \\
\text { the epidemic }\end{array}$ & $\begin{array}{l}\text { Managers' soft } \\
\text { skills } \\
\text { Organizational } \\
\text { resilience }\end{array}$ \\
\hline
\end{tabular}


TABle 1: Continued.

\begin{tabular}{|c|c|c|c|c|c|c|c|c|}
\hline $\begin{array}{l}\text { Name of } \\
\text { the first } \\
\text { author }\end{array}$ & Year & Period & Objectives & Databases & $\begin{array}{l}\text { Number } \\
\text { of } \\
\text { reviewed } \\
\text { articles }\end{array}$ & Meta & Findings & Subset \\
\hline $\begin{array}{l}\text { Raphael } \\
\text { et al. [19] }\end{array}$ & 2021 & Till 30.04.2021 & $\begin{array}{l}\text { Investigating the } \\
\text { adaptability of } \\
\text { providing mental } \\
\text { health services } \\
\text { during the } \\
\text { outbreak of } \\
\text { COVID-19 }\end{array}$ & $\begin{array}{c}\text { CINAHL, } \\
\text { EMBASE, } \\
\text { Medline, } \\
\text { PsycINFO, and } \\
\text { Web of Science }\end{array}$ & 19 & $\mathrm{~N}$ & $\begin{array}{l}\text { Mental health } \\
\text { services need to } \\
\text { consider infection } \\
\text { control measures } \\
\text { and implement } \\
\text { service changes to } \\
\text { support continuity } \\
\text { of care and patient } \\
\text { and staff } \\
\text { wellbeing. Services } \\
\text { also need to ensure } \\
\text { they communicate } \\
\text { important } \\
\text { information in a } \\
\text { clear and } \\
\text { accessible manner } \\
\text { with their staff and } \\
\text { patients regarding } \\
\text { service delivery, } \\
\text { contagion } \\
\text { symptoms, } \\
\text { government } \\
\text { guidelines, and } \\
\text { wellbeing }\end{array}$ & $\begin{array}{c}\text { Managers' soft } \\
\text { skills }\end{array}$ \\
\hline $\begin{array}{l}\text { Pappa et al. } \\
{[20]}\end{array}$ & 2020 & Till 17.04.2020 & $\begin{array}{l}\text { Evaluating the } \\
\text { prevalence of } \\
\text { depression, } \\
\text { anxiety, or } \\
\text { insomnia }\end{array}$ & $\begin{array}{l}\text { MEDLINE, } \\
\text { PubMed, and } \\
\text { Google Scholar }\end{array}$ & 13 & $\mathrm{Y}$ & $\begin{array}{l}\text { Compared with } \\
\text { men and medical } \\
\text { staff, women and } \\
\text { nurses show more } \\
\text { emotional } \\
\text { symptoms } \\
\text { associated with } \\
\text { anxiety and } \\
\text { depression. } \\
\text { Special } \\
\text { arrangements such } \\
\text { as the provision of } \\
\text { protective } \\
\text { equipment for } \\
\text { staff and their } \\
\text { family should be } \\
\text { made to protect } \\
\text { their mental } \\
\text { health. }\end{array}$ & $\begin{array}{l}\text { Motivation- } \\
\text { hygiene } \\
\text { measures }\end{array}$ \\
\hline $\begin{array}{l}\text { Gross et al. } \\
{[21]}\end{array}$ & 2021 & Till 26.04.2020 & $\begin{array}{l}\text { 1. Examining } \\
\text { HCV's physical } \\
\text { and mental health } \\
\text { status in the } \\
\text { COVID-19 } \\
\text { situation } \\
\text { 2. Detecting } \\
\text { corona risk } \\
\text { prevention } \\
\text { measures }\end{array}$ & $\begin{array}{c}\text { PsycINFO, Web } \\
\text { of Science, and } \\
\text { PubMed }\end{array}$ & 27 & $\mathrm{~N}$ & $\begin{array}{l}\text { Because of the } \\
\text { high exposure of } \\
\text { healthcare staff to } \\
\text { COVID-19, it is } \\
\text { necessary to } \\
\text { 1. make the } \\
\text { workplace safe } \\
2 \text {. increase the } \\
\text { healthcare staff } \\
\text { information level } \\
\text { of how infections } \\
\text { outbreak and } \\
\text { affect health }\end{array}$ & $\begin{array}{l}\text { Motivation- } \\
\text { hygiene } \\
\text { measures }\end{array}$ \\
\hline
\end{tabular}


Table 1: Continued.

\begin{tabular}{|c|c|c|c|c|c|c|c|c|}
\hline $\begin{array}{l}\text { Name of } \\
\text { the first } \\
\text { author }\end{array}$ & Year & Period & Objectives & Databases & $\begin{array}{l}\text { Number } \\
\text { of } \\
\text { reviewed } \\
\text { articles }\end{array}$ & Meta & Findings & Subset \\
\hline $\begin{array}{l}\text { Bhaumik } \\
\text { et al. [22] }\end{array}$ & 2020 & 2020 & $\begin{array}{l}\text { Identifying } \\
\text { CHW' principal } \\
\text { roles, issues, } \\
\text { obstacles, and } \\
\text { activators to } \\
\text { respond to the } \\
\text { pandemic }\end{array}$ & $\begin{array}{l}\text { PubMed, } 18 \\
\text { websites of } \\
\text { different } \\
\text { government } \\
\text { ministries (India, } \\
\text { Australia, and } \\
\text { Singapore), } \\
\text { public health } \\
\text { agencies (from } \\
\text { China, US, South } \\
\text { Africa, UK, } \\
\text { Hong Kong, and } \\
\text { Australia), } \\
\text { multinational } \\
\text { agencies (WHO, } \\
\text { European CDC, } \\
\text { and African } \\
\text { CDC), COVID- } \\
\text { 19 resource } \\
\text { aggregators } \\
\text { available at the } \\
\text { time of review } \\
\text { (Wiley, Elsevier, } \\
\text { Oxford } \\
\text { University Press, } \\
\text { New England } \\
\text { Journal of } \\
\text { Medicine, } \\
\text { Journal of the } \\
\text { American } \\
\text { Medical } \\
\text { Association), } \\
\text { and preprints } \\
\text { (medRxiv) }\end{array}$ & 36 & $\mathrm{~N}$ & $\begin{array}{l}\text { Dorion play a } \\
\text { Healthcare } \\
\text { workers potal role in } \\
\text { pandemics. In } \\
\text { addition to job } \\
\text { satisfaction and } \\
\text { workers' health, it } \\
\text { is necessary to } \\
\text { ensure role } \\
\text { transparency, } \\
\text { education, } \\
\text { support, and } \\
\text { supervision }\end{array}$ & $\begin{array}{c}\text { Managers' soft } \\
\text { skills } \\
\text { Motivation- } \\
\text { hygiene } \\
\text { measures }\end{array}$ \\
\hline
\end{tabular}


TABle 1: Continued.

\begin{tabular}{|c|c|c|c|c|c|c|c|c|}
\hline $\begin{array}{l}\text { Name of } \\
\text { the first } \\
\text { author }\end{array}$ & Year & Period & Objectives & Databases & $\begin{array}{l}\text { Number } \\
\text { of } \\
\text { reviewed } \\
\text { articles }\end{array}$ & Meta & Findings & Subset \\
\hline $\begin{array}{l}\text { Pollock } \\
\text { et al. [23] }\end{array}$ & 2020 & 2002-2020 & $\begin{array}{l}\text { 1. Evaluating the } \\
\text { intervention } \\
\text { effects aimed at } \\
\text { supporting the } \\
\text { frontline } \\
\text { healthcare } \\
\text { professionals' } \\
\text { resilience and } \\
\text { mental health } \\
\text { during the } \\
\text { outbreak of } \\
\text { disease and } \\
\text { epidemics } \\
\text { 2. Identifying } \\
\text { obstacles and } \\
\text { facilitators } \\
\text { effective in } \\
\text { performing } \\
\text { interventions } \\
\text { aimed at } \\
\text { supporting } \\
\text { frontline } \\
\text { healthcare } \\
\text { professionals' } \\
\text { resilience and } \\
\text { mental health } \\
\text { during the } \\
\text { outbreak of } \\
\text { disease and } \\
\text { epidemics }\end{array}$ & $\begin{array}{c}\text { CENTRAL, } \\
\text { MEDLINE, } \\
\text { EMBASE, Web } \\
\text { of Science, } \\
\text { PsycINFO, } \\
\text { CINAHL, Global } \\
\text { Index Medicus } \\
\text { databases, and } \\
\text { WHO }\end{array}$ & 16 & $\mathrm{~N}$ & $\begin{array}{l}\text { } \\
\text { Frontline } \\
\text { healthcare } \\
\text { professionals' } \\
\text { mental health and } \\
\text { resilience during } \\
\text { epidemics can be } \\
\text { improved by } \\
\text { workplace } \\
\text { interventions, } \\
\text { supportive } \\
\text { interventions to } \\
\text { meet basic daily } \\
\text { needs, } \\
\text { psychopathic } \\
\text { interventions, } \\
\text { health } \\
\text { interventions, or a } \\
\text { combination of } \\
\text { these. }\end{array}$ & $\begin{array}{l}\text { Motivation- } \\
\text { hygiene } \\
\text { measures } \\
\text { Managers' soft } \\
\text { skills }\end{array}$ \\
\hline $\begin{array}{l}\text { Timbie } \\
\text { et al. [24] }\end{array}$ & 2013 & 1990-2011 & $\begin{array}{l}\text { The analysis of } \\
\text { scarce resource } \\
\text { allocation } \\
\text { management } \\
\text { strategies }\end{array}$ & $\begin{array}{c}\text { Medline, Scopus, } \\
\text { EMBASE, } \\
\text { Cumulative } \\
\text { Index to Nursing } \\
\text { and Allied health } \\
\text { literature, Global } \\
\text { Health, Web of } \\
\text { Science, } \\
\text { Cochrane, New } \\
\text { York Academy } \\
\text { of Medicine's } \\
\text { Grey literature } \\
\text { report, and key } \\
\text { websites }\end{array}$ & 74 & $\mathrm{~N}$ & $\begin{array}{l}\text { Scarce resource } \\
\text { allocation } \\
\text { management } \\
\text { strategies during } \\
\text { collective } \\
\text { explosion events } \\
\text { include } \\
\text { 1. reducing } \\
\text { demand for } \\
\text { healthcare services } \\
\text { 2. optimizing the } \\
\text { use of available } \\
\text { resources } \\
\text { 3. increasing } \\
\text { existing resources } \\
\text { 4. implementing } \\
\text { crisis treatment } \\
\text { standards and } \\
\text { hybrid strategies }\end{array}$ & $\begin{array}{l}\text { Organizational } \\
\text { resilience }\end{array}$ \\
\hline
\end{tabular}


TABLE 1: Continued.

\begin{tabular}{|c|c|c|c|c|c|c|c|c|}
\hline $\begin{array}{l}\text { Name of } \\
\text { the first } \\
\text { author }\end{array}$ & Year & Period & Objectives & Databases & $\begin{array}{l}\text { Number } \\
\text { of } \\
\text { reviewed } \\
\text { articles }\end{array}$ & Meta & Findings & Subset \\
\hline $\begin{array}{l}\text { Allan et al. } \\
{[25]}\end{array}$ & 2020 & Till 30.03.2020 & $\begin{array}{l}\text { Examining } \\
\text { HCWs' mental } \\
\text { health disorders } \\
\text { regarding the } \\
\text { increasing rate of } \\
\text { hospital } \\
\text { admissions and } \\
\text { mortality due to } \\
\text { COVID-19 }\end{array}$ & $\begin{array}{c}\text { Medline, } \\
\text { PsycINFO, } \\
\text { CINAHL, } \\
\text { PubMed, OVID, } \\
\text { and } \\
\text { ScienceDirect }\end{array}$ & 19 & $\mathrm{Y}$ & $\begin{array}{l}\text { Mental health } \\
\text { disorders are } \\
\text { common among } \\
\text { healthcare workers } \\
\text { in contact with } \\
\text { patients during the } \\
\text { epidemic, but the } \\
\text { trend of these } \\
\text { disorders has not } \\
\text { been completely } \\
\text { understood. More } \\
\text { followup of } \\
\text { healthcare workers } \\
\text { is necessary. }\end{array}$ & $\begin{array}{c}\text { Managers' soft } \\
\text { skills }\end{array}$ \\
\hline $\begin{array}{l}\text { De Brier } \\
\text { et al. [26] }\end{array}$ & 2020 & Till 28.03.2021 & $\begin{array}{l}\text { Identifying risk } \\
\text { and protective } \\
\text { factors of HCW's } \\
\text { mental health } \\
\text { during the corona } \\
\text { epidemic }\end{array}$ & $\begin{array}{c}\text { MEDLINE, } \\
\text { EMBASE, } \\
\text { PsycINFO, } \\
\text { WHO, and CDC }\end{array}$ & 33 & $\mathrm{~N}$ & $\begin{array}{l}\text { There are some } \\
\text { pieces of evidence } \\
\text { indicating that } \\
\text { clear } \\
\text { communication, } \\
\text { organizational } \\
\text { support, social } \\
\text { support, and a } \\
\text { sense of personal } \\
\text { control are } \\
\text { protective factors } \\
\text { against mental } \\
\text { consequences. }\end{array}$ & $\begin{array}{c}\text { Managers' soft } \\
\text { skills }\end{array}$ \\
\hline
\end{tabular}

participation in decision-making increase the staff's willingness to work and, consequently, their maintenance in the organization [34]. Furthermore, Pavani Rangachari's investigations in 2017 indicated that excluding nurses from the decision-making process was the leading cause of job burnout [33]. According to Chia-Ching Wu's research findings on nurses' willingness to care for patients with SARS in 2012, the workers' willingness to work during crisis periods does not change significantly, and the majority of workers are willing or unwilling under normal conditions. In this investigation, considering their financial needs, family support, safeguarding individual health, and human resource policies, nurses found it a better decision to stay in their jobs during the outbreak of SARS [24]. Therefore, motivation-hygiene measures need to be adopted under both crisis and normal condition [13-15] since workers' reluctance to work in both conditions reduces the quality of work and service even if it does not make workers quit their jobs. This will be more alarming under the crisis condition.

Nevertheless, Mary Chaffee's findings are in contrast with those reported by Chia-Ching Wu. Considering 30 studies, she stated that biological events might significantly decrease individuals' willingness to work; however, the provision of protective and training equipment is likely to improve their willingness [35]. According to the critical role of motivation-hygiene measures in establishing trust, they are of great importance in promoting job satisfaction and willingness to work, and precise economic planning should be proposed to provide their financial resources [36,37]. To manage crisis and achieve the best results under the crisis, the measures can be categorized according to their priority. According to Herzberg's motivation-hygiene theory, hygienic factors such as security, work, and salary decrease dissatisfaction; however, they cannot enhance satisfaction. This is while motivational factors promote job satisfaction. According to workers' needs, an increase in motivationhygiene measures can play a pivotal role in maintaining workers in the long-term crises. These measures in healthcare systems include the provision of protective equipment required by workers, shift change programs to let the worker rest [12], information dissemination [24], training programs, and increased awareness in dealing with illness, all of which would decrease their feelings of fear [13]. High work pressure should also be considered since it has negative effects on the nurses' performance. In this regard, if a nurse's mistake aroused by high work pressure under a crisis condition makes a patient die or get worse, the consequences have destructive effects on the nurse's morals and her/his willingness to continue working [38]. Accordingly, employee new graduates and entrusting simple tasks to these individuals would make more experienced health workers have more time and concentrate on handling high-level care services [3]. Moreover, if it is possible not to reduce salaries with a decrease in work hours, a motivation-hygiene 
measure should be adopted, which would have a positive effect during the crisis period [39]. The provision of personal protective equipment can significantly influence individuals' mental and physical health. It makes workers be less concerned with their health status and their families' health, as such the likelihood of disease transmission is decreased [33, 38]. Moreover, training, public health, families' awareness of mental and social supports, and the appreciation of workers are considered motivation-hygiene measurements that positively influence workers' mental and physical health and prevent job burnout and the loss of healthcare workers under such conditions [15].

One of the main study findings was the necessity of developing managers' soft skills. The skills are as significant as establishing an intimate relationship with workers to promote organizational resilience in crisis. Organizations with more competent managers respond to crises better $[14,40]$. Establishing effective relationship under critical conditions promotes trust among workers [33]. Trust as the driving force of ethics and the incentive for employees is of great importance for organizations, especially in crisis since psychological trust and safety are the prerequisites of organizational resilience in health organizations [33, 41]. Such measures require not many financial resources; however, managers' attention and managerial skills are of paramount importance. The measures include tasks such as listening to workers, learning from their personal problemsolving experiences, making clear strategies to support and manage workers, and generally sparing efforts to build trust.

Moreover, given that these measures can create a sense of trust in employees, providing opportunities to promote employees in crises had positive effects on the maintenance of workers in the organization in crisis [42]. The sense of trust and mental safety among healthcare workers is necessary to let them convey their concerns to managers under such conditions since managers can eliminate the leading causes of mistakes and hinder their recurrence [33]. According to the Social Exchange Theory (SET), when employees find the organization a supportive environment, where their social-emotional needs are met and favorable working conditions are provided, a psychological attachment is created, making them committed to the organization [43].

In general, flexibility in strategic planning and human resource planning and the provision of motivation-hygiene measures for employees can improve the likelihood of survival for health workers under critical conditions. This comes true, especially if these measures are accompanied with promoting managers' soft skills to establish an effective relationship having significant positive effects on the maintenance of individuals and improving their performance in the organization [42].

The strengths of our study include the use of appropriate databases in identifying potentially eligible review studies, providing search strategy in detail, selecting the studies based on AMSTAR, and reporting based on a PRISMA 2020 checklist. The limitations of our study may be due to the use of systematic reviews with no registration predetermined protocol. Although we searched the Cochrane database for unplanned duplication, the study protocol was only registered at the Student Research Committee after the Research Ethics Committee confirming to enable the representative of the Research Vice-Chancellor at Hamadan University of Medical Sciences in comparing the reported review with what was planned in the protocol.

\section{Conclusion}

In the present review study, three dimensions (namely, resilience, motivation-hygiene measures, and development of managers' soft skills) are identified as the main factors maintaining employees in healthcare centers in long-term crises. Incentives and motivational measures promote job satisfaction among employees and consequently increase their willingness to work and stay in a concerned organization. Under crisis, only motivational measures are not enough to maintain employees in the organization, and managers need to be equipped with strong soft skills as communication skills to meet the employees' physical and psychological needs and build trust among them. Some further plans and programs should be put forth to be performed in the best way to maintain workers in organizations.

\section{Data Availability}

The data are available by contact with the corresponding author.

\section{Ethical Approval}

Ethical approval was obtained with reference number: IR.UMSHA.REC.1399.819.

\section{Conflicts of Interest}

No potential conflicts of interest were reported by the authors.

\section{Authors' Contributions}

M. Khatiban and A. M. Salehi contributed to the conception and design. M. Khatiban contributed to the administrative support. F. Shavandi, M. Kavand, M. Masumi, A. M. Salehi, M. Masumi, and E. Jenabi contributed to the provision of study materials. A. M. Salehi and M. Khatiban contributed to the collection and assembly of data. S. Khazaei and M. Khatiban contributed to the data analysis and interpretation. All authors contributed to manuscript writing and final approval of the manuscript.

\section{Acknowledgments}

This study was financially supported by the Student Research Committee at Hamadan University of Medical Sciences (ID: 9912058771). 


\section{Supplementary Materials}

Supplementary 1: the PRISMA checklist. The Preferred Reporting Items for Systematic Reviews and Meta-Analysis (PRISMA) is a 27-item checklist used to improve transparency in systematic reviews. These items cover all aspects of the manuscript, including title, abstract, introduction, methods, results, discussion, and funding. Supplementary 2: evaluating the quality of articles using AMSTAR checklist. The included articles were evaluated using a checklist entitled "Measurement Tool to Assess Systematic Reviews (AMSTAR)" [11] to assess methodological quality. The tool consists of 11 items and has good face and content validity for measuring the methodological quality of systematic reviews. (Supplementary Materials)

\section{References}

[1] N. B. Said and V. C. L. Chiang, “The knowledge, skill competencies, and psychological preparedness of nurses for disasters: a systematic review," International Emergency Nursing, vol. 48, Article ID 100806, 2020.

[2] S. K. Brooks, R. Dunn, R. Amlôt, G. J. Rubin, and N. Greenberg, "Protecting the psychological wellbeing of staff exposed to disaster or emergency at work: a qualitative study," BMC psychology, vol. 7, no. 1, pp. 78-11, 2019.

[3] E. J. Collado-Boira, E. Ruiz-Palomino, P. Salas-Media, A. Folch-Ayora, M. Muriach, and P. Baliño, “"The COVID-19 outbreak"-an empirical phenomenological study on perceptions and psychosocial considerations surrounding the immediate incorporation of final-year Spanish nursing and medical students into the health system," Nurse Education Today, vol. 92, Article ID 104504, 2020.

[4] K. Qureshi, R. R. Gershon, M. F. Sherman et al., "Health care workers' ability and willingness to report to duty during catastrophic disasters," Journal of Urban Health: Bulletin of the New York Academy of Medicine, vol. 82, no. 3, pp. 378388, 2005.

[5] D. Koh, M. K. Lim, S. E. Chia et al., "Risk perception and impact of severe acute respiratory syndrome (SARS) on work and personal lives of healthcare workers in Singapore," Medical Care, vol. 43, no. 7, pp. 676-682, 2005.

[6] S. Verma, S. Mythily, Y. H. Chan, J. P. Deslypere, E. K. Teo, and S. A. Chong, "Post-SARS psychological morbidity and stigma among general practitioners and traditional Chinese medicine practitioners in Singapore," Annals Academy of Medicine Singapore, vol. 33, no. 6, pp. 743-748, 2004.

[7] D. F. Sacco and M. M. Ismail, "Social belongingness satisfaction as a function of interaction medium: face-to-face interactions facilitate greater social belonging and interaction enjoyment compared to instant messaging," Computers in Human Behavior, vol. 36, pp. 359-364, 2014.

[8] J. B. Carnevale and I. Hatak, "Employee adjustment and wellbeing in the era of COVID-19: implications for human resource management," Journal of Business Research, vol. 116, pp. 183-187, 2020.

[9] E. Barasa, R. Mbau, and L. Gilson, "What is resilience and how can it be nurtured? a systematic review of empirical literature on organizational resilience," International Journal of Health Policy and Management, vol. 7, no. 6, pp. 491-503, 2018.

[10] P. Caligiuri, H. De Cieri, D. Minbaeva, A. Verbeke, and A. Zimmermann, "International HRM insights for navigating the COVID-19 pandemic: implications for future research and practice," Journal of International Business Studies, vol. 51, pp. 697-713, 2020.

[11] B. J. Shea, J. M. Grimshaw, G. A. Wells et al., "Development of AMSTAR: a measurement tool to assess the methodological quality of systematic reviews," BMC Medical Research Methodology, vol. 7, no. 1, pp. 10-17, 2007.

[12] A. E. Muller, E. V. Hafstad, J. P. W. Himmels et al., "The mental health impact of the covid-19 pandemic on healthcare workers, and interventions to help them: a rapid systematic review," Psychiatry Research, vol. 293, Article ID 113441, 2020.

[13] S. Cabarkapa, S. E. Nadjidai, J. Murgier, and C. H. Ng, "The psychological impact of COVID-19 and other viral epidemics on frontline healthcare workers and ways to address it: a rapid systematic review," Brain, Behavior, \& Immunity-Health, vol. 8, Article ID 100144, 2020.

[14] M. Willis-Shattuck, P. Bidwell, S. Thomas, L. Wyness, D. Blaauw, and P. Ditlopo, "Motivation and retention of health workers in developing countries: a systematic review," BMC Health Services Research, vol. 8, no. 1, pp. 1-8, 2008.

[15] R. Fernandez, H. Lord, E. Halcomb et al., "Implications for COVID-19: a systematic review of nurses' experiences of working in acute care hospital settings during a respiratory pandemic," International Journal of Nursing Studies, vol. 111, Article ID 103637, 2020.

[16] G. S. Anderson, P. M. Di Nota, D. Groll, and R. N. Carleton, "Peer support and crisis-focused psychological interventions designed to mitigate post-traumatic stress injuries among public safety and frontline healthcare personnel: a systematic review," International Journal of Environmental Research and Public Health, vol. 17, no. 20, p. 7645, 2020.

[17] Y. Aoyagi, C. R. Beck, R. Dingwall, and J. S. Nguyen-VanTam, "Healthcare workers' willingness to work during an influenza pandemic: a systematic review and meta-analysis," Influenza and other respiratory viruses, vol. 9, no. 3, pp. 120-130, 2015.

[18] J. Ashcroft, M. H. Byrne, P. A. Brennan, and R. J. Davies, "Preparing medical students for a pandemic: a systematic review of student disaster training programmes," Postgraduate Medical Journal, vol. 97, no. 1148, pp. 368-379, 2020.

[19] J. Raphael, R. Winter, and K. Berry, "Adapting practice in mental healthcare settings during the COVID-19 pandemic and other contagions: systematic review," BJPsych Open, vol. 7, no. 2, p. e62, 2021.

[20] S. Pappa, V. Ntella, T. Giannakas, V. G. Giannakoulis, E. Papoutsi, and P. Katsaounou, "Prevalence of depression, anxiety, and insomnia among healthcare workers during the COVID-19 pandemic: a systematic review and meta-analysis," Brain, Behavior, and Immunity, vol. 88, pp. 901-907, 2020.

[21] J. V. Gross, J. Mohren, and T. C. Erren, "COVID-19 and healthcare workers: a rapid systematic review into risks and preventive measures," BMJ open, vol. 11, no. 1, Article ID e042270, 2021.

[22] S. Bhaumik, S. Moola, J. Tyagi, D. Nambiar, and M. Kakoti, "Community health workers for pandemic response: a rapid evidence synthesis," BMJ Global Health, vol. 5, no. 6, Article ID e002769, 2020.

[23] A. Pollock, P. Campbell, J. Cheyne et al., "Interventions to support the resilience and mental health of frontline health and social care professionals during and after a disease outbreak, epidemic or pandemic: a mixed methods systematic review," Cochrane Database of Systematic Reviews, vol. 11, no. 11, 2020. 
[24] J. W. Timbie, J. S. Ringel, D. S. Fox et al., "Systematic review of strategies to manage and allocate scarce resources during mass casualty events," Annals of Emergency Medicine, vol. 61, no. 6, pp. 677-689, Article ID e101, 2013.

[25] S. M. Allan, R. Bealey, J. Birch et al., "The prevalence of common and stress-related mental health disorders in healthcare workers based in pandemic-affected hospitals: a rapid systematic review and meta-analysis," European Journal of Psychotraumatology, vol. 11, no. 1, Article ID 1810903, 2020.

[26] N. De Brier, S. Stroobants, P. Vandekerckhove, and E. De Buck, "Factors affecting mental health of health care workers during coronavirus disease outbreaks (SARS, MERS \& COVID-19): a rapid systematic review," PLoS One, vol. 15, no. 12, Article ID e0244052, 2020.

[27] B. S. Institution, BSI 65000:2014 Guidance on Organisational Resilience, BSI Standards Publication, UK, 2014.

[28] J. Hillmann and E. Guenther, "Organizational resilience: a valuable construct for management research?” International Journal of Management Reviews, vol. 23, no. 1, pp. 7-44, 2021.

[29] Y. Kim, "Organizational resilience and employee work-role performance after a crisis situation: exploring the effects of organizational resilience on internal crisis communication," Journal of Public Relations Research, vol. 32, no. 1-2, pp. $47-75,2020$.

[30] C. M. Stello, "Herzberg's two-factor theory of job satisfaction: an integrative literature review," 2011 Student Research Conference: Exploring Opportunities in Research, Policy, and Practice, University of Minnesota Department of Organizational Leadership, Policy and Development, Minneapolis, MN, USA, 2011.

[31] B. Cimatti, "Definition, development, assessment of soft skills and their role for the quality of organizations and enterprises," International Journal for Quality Research, vol. 10, no. 1, pp. 97-130, 2016.

[32] M. R. Dal Poz, N. Gupta, E. Quain, A. L. Soucat, and W. H. Organization, Handbook on Monitoring and Evaluation of Human Resources for Health: With Special Applications for Low-And Middle-Income Countries, World Health Organization, Geneva, Switzerland, 2009.

[33] P. Rangachari and J. L. Woods, "Preserving organizational resilience, patient safety, and staff retention during COVID19 requires a holistic consideration of the psychological safety of healthcare workers," International Journal of Environmental Research and Public Health, vol. 17, no. 12, p. 4267, 2020.

[34] H. Rajnbar and H. Shafizadeh, "Identify and prioritize the factors affecting the survival and sustainability of municipal employees in district 13 in Tehran," Urban Management Studies, vol. 7, no. 24, pp. 64-77, 2016.

[35] M. Chaffee, "Willingness of health care personnel to work in a disaster: an integrative review of the literature," Disaster Medicine and Public Health Preparedness, vol. 3, no. 1, pp. 42-56, 2009.

[36] A. J. Dawson, H. Stasa, M. A. Roche, C. S. Homer, and C. Duffield, "Nursing churn and turnover in Australian hospitals: nurses perceptions and suggestions for supportive strategies," BMC Nursing, vol. 13, no. 1, pp. 11-10, 2014.

[37] G. Mostafa, A. Jamshid, and K. K. Hussein, "Investigating the factors affecting the organizational sustainability of human resources," vol. 29, pp. 29-40, 2008.

[38] N. Greenberg and D. Tracy, "What healthcare leaders need to do to protect the psychological well-being of frontline staff in the COVID-19 pandemic," BMJ Leader, vol. 4, no. 3, 2020.
[39] H. Rangriz and S. Z. Moosavi, "General health policies and the effect of burnout by overworks on the shortage of nurses in Iranian hospitals," Quarterly Journal of the Macro and Strategic Policies, vol. 2, no. 7, pp. 43-64, 2014.

[40] F. Ssengooba, S. A. Rahman, C. Hongoro et al., "Health sector reforms and human resources for health in Uganda and Bangladesh: mechanisms of effect," Human Resources for Health, vol. 5, no. 1, pp. 3-13, 2007.

[41] P. Vardarlier, "Strategic approach to human resources management during crisis," Procedia-Social and Behavioral Sciences, vol. 235, pp. 463-472, 2016.

[42] M. I. Ansari, F. Dehghanianari, and G. Shahbazi, "Investigating the relationship between health motivational factors with satisfaction and Occupational dissatisfaction with the use of Herzberg theory (case study: isfahan's staff)," Quarterly Journal of Law Enforcement Management Studies, vol. 7, no. 2, pp. 178-196, 2012.

[43] C. R. Makanjee, Y. F. Hartzer, and I. L. Uys, "The effect of perceived organizational support on organizational commitment of diagnostic imaging radiographers," Radiography, vol. 12, no. 2, pp. 118-126, 2006. 